Salih Bardakci'

Department of Computer and Instructional Technologies Education,

Tokat Gaziosmanpasa University, Tokat, Turkey

Dilara Cayci Karakose ${ }^{2}$

Department of Educational Sciences, Tokat Gaziosmanpasa University,

Tokat, Turkey

Derya Colkesen Alkis 3

Department of Tourism and Hotel Management, Tokat Gaziosmanpasa University,

Tokat, Turkey

Muhammet Fatih Alkan ${ }^{4}$

Department of Educational Sciences, Tokat Gaziosmanpasa University,

Tokat, Turkey

\title{
HOW TO BECOME A CONSTRUCTIVIST TEACHER? THE IMPACT OF PHILOSOPHICAL THOUGHTS ON CONSTRUCTIVIST LEARNING BELIEFS 5
}

\begin{abstract}
This study aimed at investigating the causal relationships among teachers' constructivist learning beliefs, philosophical beliefs regarding the learning process, epistemological beliefs regarding the nature of knowledge and learning, vocational development opportunities, and the importance attached to these opportunities. In this direction, the causal relationships among these variables were tested through structural equation modelling using the data obtained from teachers working at basic education schools in Turkey. Constructivist Learning Beliefs Scale, Educational Beliefs Scale, Professional Development Scale, and Epistemological Beliefs Scale were used as the data collection tools. The results showed that philosophical beliefs, epistemological beliefs, and thoughts on vocational development opportunities significantly predicted teachers' constructivist learning beliefs.

Keywords: constructivist learning belief; educational belief; importance placed on professional development; epistemological belief.
\end{abstract}

\section{Introduction}

A constructive transformation has been carried out in the Basic Education Curriculum in Turkey since 2004. By the 2008-2009 academic year, constructivist curricula started to be used at all stages of education. However, while curricula include activities and processes based on constructivist teaching strategies, it appears that teachers diverge from this approach in

\footnotetext{
${ }^{1}$ salihbardakci@hotmail.com

2dilara.caycikarakose@gmail.com

3 deryacolkesen@gmail.com

${ }^{4}$ mfatihalkan@hotmail.com https://orcid.org/0000-0002-5600-0160

5 This paper is expanded version of the study presented at the $5^{\text {th }}$ International Congress on Curriculum and Instruction, 26-28 October 2017 in Muğla, TURKEY.
} 
practice (Gul, 2016; Duru, 2006; Arslan, 2009). Arslan (2009) revealed in his study that classroom activities were far from the constructivist approach that the curriculum projected. He indicated that new technologies and materials were not being made use of, the environment and materials were not planned with students, and methods and techniques to ensure high-level thinking were not used. Similarly, Anagun, Yalcinoglu, and Ersoy (2012) found that of 15 teachers, only one-third of the participants adopted constructivist philosophy; but only two teachers brought constructivist teaching practices into the classroom environment. The main reason for that situation was the obligation of preparing the students for the standardized tests which were created by the transition system to the university. Another reason could be the fact that the Ministry of National Education seems to have a behaviouristic approach rather than making any regulations to enhance the applicability of constructivism. Concerning this, teachers also have more responsibilities and course load (Celikoz and Erisen, 2017). Ekici, Aldan Karademir, Ucak, and Ekici (2011) also showed that constructivist practices did not find enough room in the classroom and the reason for this was that teachers did not feel that they had enough education and experience about constructivist teaching activities. Accordingly, it can be expressed that learning of constructivism in Turkey during teacher education or training remains at the theoretical level and does not include direct or indirect experiences. Academic staff from the faculty of education consider that teacher training programs do not provide opportunities for constructive practice and even if the academic staff try to give place to constructivist practices during their courses, it can be said that they do not completely apply constructivism. Thus, prospective teachers graduate only with cognition and comprehension level of knowledge but they cannot reach the practice level (Celikoz and Erisen, 2017). Therefore, it is very difficult for teachers to develop activities that are solely based on the theoretical basis.

In general, it is seen that preliminary research emphasizes the technological and pedagogical possibilities and competencies of teachers about the failure of the expected constructive transformation in the teaching-learning process. Besides, it is thought that another group of factors in the transition to constructivist teaching processes might be teachers' philosophies and beliefs related to the nature of knowledge, learning, and teaching. In this regard, it is aimed to examine the causal relations between teachers' beliefs of constructivist learning and their philosophical approaches to teaching processes, their epistemological belief regarding the nature of knowledge and learning, as well as the professional development opportunities they have, and the importance they attach to them.

\section{Literature Review and Hypotheses}

Nowadays, there is a necessity for continuous learning and self-development for the people of the information society (Kim, 2016; Volles, 2014). This changes the purpose of education into raising people with the ability to develop new products, ideas, and perspectives rather than transferring specific knowledge, skills, work style, attitudes, or values (Buckner, 2016). This understanding highlights constructivist theory in the design and maintenance of both curricula and classroom activities (Palmaru, 2016).

Constructivism is fundamentally a paradigm that is interested in how knowing and learning are done. According to the constructivist paradigm, individuals' knowledge is the interpretation they have developed based on their own experience (Jonassen, 1991). In other words, people do not take the meaning from outside, they create it. Even just a different experience may affect an individual's interpretation/meaning development process. 
Therefore, there is no single truth or meaning (Deryakulu, 2000). The constructivist teaching approach focuses not only on the transfer of knowledge from the outside world into the memory of the learner but also on each learner's creating own meaning and giving (reflecting) it to the world through experience and interaction. In such a learning environment, the internal representation of knowledge is open to change, which means there is no objective reality that learners need to know (Ertmer and Newby, 2013).

As a consequence of the shift from the cognitive to the constructivist understanding in the 1980 s, teaching has become a profession requiring to make decisions based on one's own knowledge, beliefs, and experiences beyond a specific stereotyped practitioner who systematically implements a rigid series of classroom behaviours (Richardson, 1996). This autonomy makes beliefs important as well as professional competencies in the development and execution of class processes. The radical change proposed by constructivism about the nature of knowledge and learning poses teacher beliefs as an important factor in the implementation of constructivist teaching strategies and activities. Research shows that teachers' decisions about pedagogy or curricula are largely based on personal beliefs (Levitt, 2001; Lumpe, Haney and Czerniak, 2000; Thomson and Gregory, 2013). These notions show that teachers with constructivist beliefs are much more likely to perform learning activities based on this paradigm.

Since the 1980s, teacher beliefs have been considered as a factor affecting the achievement in the classroom in the literature (Wallace, 2014). In this respect, research conducted over the last 30 years reveals various assumptions about the nature of teacher beliefs (Bryan, 2012). According to these assumptions: (1) teachers' beliefs have a much greater influence on analyzing classroom problems, deciding on solutions, and overcoming problems than academic knowledge, (2) Some beliefs of teachers may be stronger and strong beliefs are more resistant to change, (3) Beliefs are not independent of one another; they are organized within an internal structure, (4) Teachers can have groups of rival beliefs about the same subject, and (5) When a belief changes, it may also affect other beliefs in the system. These indicators suggest that beliefs about teaching and learning are important determinants of teacher behaviour in the classroom because these beliefs can be much more effective than the academic knowledge and skills that teachers have over their professional activities. Erdem and Arkun Kocadere (2015) consider teachers' beliefs about learning and teaching to be among the main elements of the education system. Moving from Prawat's (1992) considerations, they also emphasize the need to study teacher beliefs to be successful in a constructive educational reform that requires profound changes in the teaching strategy, in other words, teacher roles and behaviours. Similarly, there is research that establishes causal relationships between teachers' beliefs about learning, teaching, or teaching processes and their teaching practices (Cronin-Jones, 1991; Ertmer, 2005; Pajares, 1992; Shagrir, 2015; Tobin and Espinet, 1989; Yuan, 2017).

In the literature, another concept associated with the teaching approaches and methods is the philosophy of education adopted by teachers (Bas, 2015; Yilmaz, Altinkurt and Cokluk, 2011). In his study in which he dealt with the relationships between teachers' philosophical beliefs of education and their understanding of teaching-learning, Bas (2015) found strong relationships between the adaptation of contemporary educational philosophies (progressivist, reconstructivist and existentialist) and constructivist teaching-learning approaches; traditional educational philosophies (prennialist and essentialist) and the preferences of traditional teaching-learning approaches. 
Another important variable associated with teachers' preferred teaching strategies is their beliefs about the nature of knowledge and learning (Aypay, 2011; Bicer, Er and Ozel, 2013). Beliefs related to the nature of knowledge and learning are conceptualized as 'epistemological beliefs' (Schommer, 1990). Preliminary studies suggest results indicating that teachers' epistemological beliefs heavily influence processes of designing, conducting, directing, or evaluating classroom activities (Cam, 2015; Huang, 2014; Ismail, 2017; Saylan, Armagan and Bektas, 2016; Yousefzadeh and Azam, 2015). Kirschner (2009) states that epistemological beliefs can lead to the teacher's teaching styles and strategies and, in this respect, the teacher's personal teaching strategy is a unique reflection of his epistemological belief. On the other hand, Bahcivan (2016) reported that preservice science teachers' epistemological beliefs were not related to their teaching beliefs. Their teaching beliefs were strongly and directly related to their previous learning and teaching experiences, instead.

Another important factor affecting teachers' attitudes and beliefs about different instructional strategies is their experience possibilities for innovative teaching practices (Howard, McGee, Schwartz and Purcell, 2000). Richardson (1996) focuses on individual life experiences, experiences as a student, and pedagogical experiences as three sources of teacher beliefs. Thus, experiences as a teacher or student of innovative teaching strategies, in other words, the opportunities available in the teachers' schools or the multiplicity of professional development possibilities can positively affect beliefs about innovative strategies. Teachers' beliefs are influenced by the interaction in the concentric social context in which beliefs and practices take place (Mansour, 2013). Howard, McGee, Schwartz, and Purcell (2000) demonstrate in their experimental work, in which they offer teachers professional development possibilities for using computer-based constructivist learning environments, that professional development possibilities improve teachers' constructivist teaching beliefs positively.

In brief, the studies show that the disruption in the implementation of the curricula which adopted the constructivist approach is not just related to the professional competencies of the practitioners, but also their beliefs about the nature of education and learning, and the professional development possibilities they have.

\section{Philosophical Beliefs Related To Teaching Processes}

Philosophical beliefs about teaching processes in this study are examined with a classification consisting of progressivism, perennialism, essentialism, existentialism, and reconstructionism. Perennialism emphasizes that people must be trained to adapt to the universal realities, which are absolutely unchangeable (Oliva, 1988). According to essentialism, the aim of education is the transfer of cultural heritage to the new generations (Oliva, 1988). With an approach that is quite different from that of perennialism and essentialism, progressivism rejects the concept of absolute reality and underlines that student-centred education should be life itself, not preparation for life (Ornstein and Levine, 2008). According to the reconstructionism that has been developed in the direction of progression, the main aim of education is to rebuild the society (Gutek, 1997). Finally, according to existentialism, education aims to increase the freedom of the individual (Ozmon and Craver, 2003). Accordingly, it is predicted that beliefs about innovation and change (progressivism, existentialism, and reconstructionism) would have a positive influence on constructivist learning beliefs while beliefs about maintaining the existing knowledge and method (perennialism and essentialism) would negatively influence them. In this direction, research hypotheses were defined as: 
H1: Progressivism beliefs adopted by teachers have a significant positive influence on their constructivist beliefs.

H2: Perennialism beliefs adopted by teachers have a significant negative influence on their constructivist beliefs.

H3: Essentialism beliefs adopted by teachers have a significant negative influence on their constructivist beliefs.

H4: Existentialism beliefs adopted by teachers have a significant positive influence on their constructivist beliefs.

H5: Reconstructionism beliefs adopted by teachers have a significant positive influence on their constructivist beliefs.

\section{Epistemological Beliefs}

In this study, epistemological beliefs were investigated with a three-component model presented by Deryakulu and Buyukozturk (2002). These components are the belief that learning depends on effort, the belief that learning depends on ability, and the belief that there is a unique truth. These beliefs can be categorized in line with the philosophical beliefs since perennialism and essentialism highlights the sole and unchanging truth and the role of ability in education (Ornstein and Levine, 2008; Tanner and Tanner, 2007). On the other hand, according to progressivists, existentialists, and reconstructivists, the effort is important during the learning process because it requires the active participation of individuals in the learning experience (Gutek, 1997; Oliva, 1988). Based on this categorization, it is foreseen that the belief that learning depends on effort would have a positive influence on constructivist learning beliefs while beliefs that learning depends on the ability and there is a unique truth would negatively influence them. In the light of these ideas, hypotheses were listed as:

H6: Teachers' belief that learning depends on effort has a significant positive influence on their constructivist beliefs.

H7: Teachers' belief that learning depends on ability has a significant negative influence on their constructivist beliefs.

H8: Teachers' belief that there is a unique truth has a significant positive influence on their constructivist beliefs.

\section{Professional Development Environment}

Howe, Jacobs, Vukelich, and Recchia (2012) note the contrast between teachers' beliefs and teaching practices and report that while they state that they have constructivist teaching beliefs, during practice they are acting in the opposite direction of this approach. Therefore, they indicate that teachers need in-service professional development to follow new trends in their fields and to improve their knowledge and practice. Sahin, Kocagul and Guler (2012) similarly emphasize the importance of professional development of teachers in the training of individuals who can adapt to current developments and changes and point out the importance of determining what teachers need in the school environment to support this development. Sahin et al. (2012) examine the professional development environment under two headings, which are teaching resources and teacher contributions, and emphasize two dimensions (availability of the related facility and the importance given to it by teachers) in both of the headings. Also, in this study with the approach of Sahin et al. (2012), it is envisaged that the availability of structures/facilities that support professional development in the school and the importance given to these structures/facilities would have a positive influence on teachers' constructivist learning beliefs. The hypotheses envisaged in this direction were as 
follows:

H9: The availability of facilities that support professional development in the school has a significant positive influence on teachers' constructivist beliefs.

H10: The importance given to professional development has a significant positive influence on teachers' constructivist beliefs.

The proposed model in the direction of research hypotheses is presented in Figure 1.

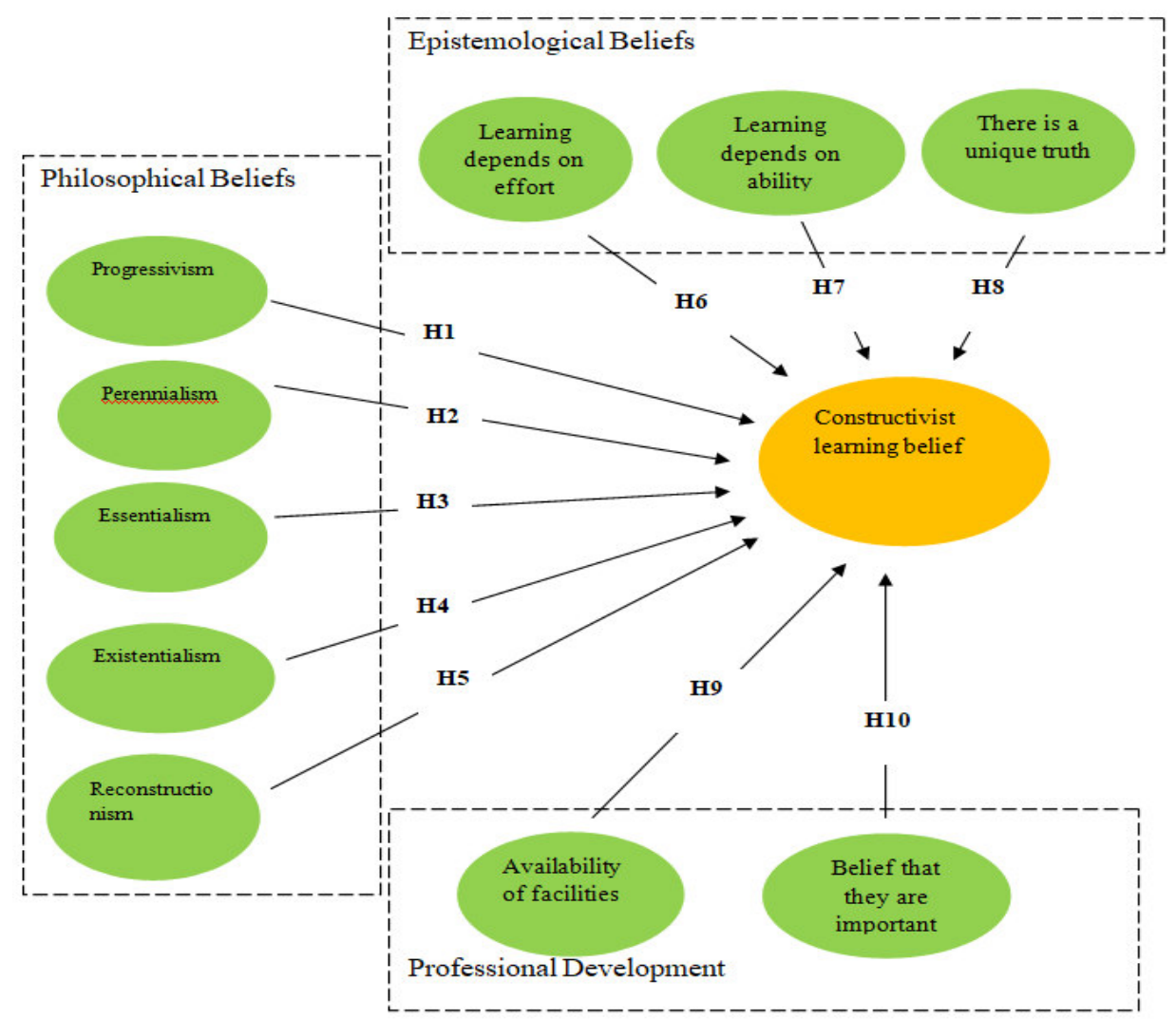

Figure 1: The hypothesized model

\section{Method}

This study employed a causal study design, one of the ex post facto designs, which is concerned with identifying the antecedents of a present condition allowing the establishment of causal relationships among the variables (Cohen, Manion and Morrison, 2005). Accordingly, the causal relationships among teachers' constructivist learning beliefs, philosophical beliefs regarding the learning process, epistemological beliefs regarding the nature of knowledge and learning, vocational development opportunities, and the importance attached to these opportunities were tested using structural equation modelling. 


\section{Participants}

The data were collected from 276 teachers who were working in different regions of Turkey and were selected randomly on a voluntary basis. The majority of participants $(n=190,68.8 \%)$ were female. The distributions according to education level were $52(18.8 \%)$ high schools, 167 (60.5\%) secondary schools, $41(14.9 \%)$ primary schools, and $16(5.8 \%)$ preschools. The age of participants ranged from 23 to 58, and the mean age was 31,46. Moreover, the mean professional experience was 8.27 years.

\section{Data Collection Tools}

Constructivist Learning Belief Scale: Constructivist Learning Belief Scale was developed by Erdem and Arkun Kocadere (2015) to measure teachers' beliefs about constructivist learning. It consists of 26 items under six factors that are rated on a 5-point Likert scale, with higher scores indicating stronger constructivist beliefs. Some sample items include students' opinions should be considered while arranging the learning environment and students should be supported so that they could discover their own learning ways. The original Cronbach Alpha coefficient was .94, which was .95 in this study.

Educational Belief Scale: Educational Belief Scale was developed by Yilmaz, Altinkurt and Cokluk (2011) to determine the beliefs of primary and secondary school teachers about the educational process. It is composed of 40 items under five factors that are rated on a 5-point Likert scale. These factors were perennialism (8), essentialism (5), progressivism (13), reconstructionism (7), and existentialism (7). Some sample items include the school is life itself rather than preparation for life and education is the process of adapting to universal and perennial reality. The Cronbach alpha internal consistency coefficients obtained in the original study for these factors were .70 or higher. These coefficients in the current study were .71 or higher. The higher score on a subscale indicates that the participants believe and admit to the underlying educational philosophy.

Professional Development Scale: The Professional Development Scale was developed by Berlin, Klapper and White (1996) for teachers and adapted to Turkish culture by Sahin, Kocagul and Guler (2012). The scale consists of 32 items rated on a 3-point Likert scale and a two-way answer is given for each item. One aspect of the answers reveals the importance of the material and the other shows whether it is available in the educational environment. Some sample items include an effective social support system and the opportunity to plan, develop, and implement useful and creative lessons in your classroom. The Cronbach alpha coefficients obtained during the adaptation were .91 for both dimensions. In the current study, this coefficient was .91 for the availability of professional development possibilities and .95 for professional development.

Epistemological Belief Scale: Epistemological Belief Scale was developed by Schommer (1990) and adapted to Turkish culture by Deryakulu and Buyukozturk (2002) for university students. The Turkish version consists of 35 items rated on a 5-point Likert scale. It involved three factors which are the belief that learning is dependent on effort (18), the belief that learning is dependent on ability (8), and the belief that there is a unique truth (9). Sample items for each factor in the respective order include if I find the time to re-read a textbook chapter, I get a lot more out of it the second time, some people are born good learners, others are just stuck with limited ability, and the best thing about science courses is that most problems have only 
one right answer. Cronbach alpha coefficients obtained from the adaptation study were .83 , .62 , and .59 , respectively. The Cronbach alpha values obtained in the current study were .85 , .89 , and .80 . The higher score from each factor indicates that the individual has undeveloped/immature epistemological beliefs for that factor (Deryakulu and Buyukozturk, 2002).

\section{Data Collection and Analysis}

The data was collected online. In this process, invitation messages were sent to the target group via various social networks and e-mail lists. This message was repeated 4 times in a period of 3 months and the data obtained from the teachers who took the message and filled the scale were kept in a database. After the data collection period, the inspections were performed on the dataset by examining the situations such as missing data or sending data over the same IP more than once. As a result, a qualified dataset of 276 participants was reached.

The model suggested in the study was tested with a structural equation model based on maximum likelihood using LISREL v.8.71 software. The significance of $X^{2}$, the ratio of $X^{2} / d f$, and other goodness of fit indices were used in the evaluation of the proposed-observed model fit. For hypothesis tests, path analysis and $\beta$ and $t$ values for each hypothesis were used.

\section{Findings}

Prior to testing the hypotheses, the assumptions of structural equation modelling and the construct validity of the data collection tools were inspected. Since structural equation modelling is a multivariate analysis, multivariate outliers were checked through Mahalanobis Distance. Analysis on SPSS.25 yielded five possible outliers according to the $p<.001$ criterion of Kline (2005). As suggested by Aguinis, Gottfredson, and Joo (2013), the path analysis was carried out with and without the multivariate outliers, which demonstrated that these outliers were not influential. Therefore, they were not excluded from the dataset. Secondly, the correlation coefficients were inspected to check the multicollinearity, which demonstrated that the correlation coefficients among the constructs varied between -.12 and .82 . Kline (2005) suggests that correlation coefficients below .90 indicate that there is no multicollinearity problem. Thirdly, skewness and kurtosis values were examined to check the multivariate normality. All of the kurtosis and skewness values except for existentialism kurtosis were below the thresholds indicated by Kline (2005) as $<10$ for kurtosis and $<3$ for skewness. The descriptive statistics and skewness-kurtosis values are illustrated in Table 1.

Table 1. Descriptive statistics of constructs

\begin{tabular}{llcll}
\hline Constructs & Mean & $\begin{array}{l}\text { Std. } \\
\text { Deviation }\end{array}$ & Skewness & Kurtosis \\
\hline Constructivist Learning Belief & 4.28 & .54 & $-1,60$ & 5.97 \\
Progressivism & 4.30 & .55 & -2.02 & 9.13 \\
Perennialism & 3.90 & .65 & -.66 & 1.65 \\
Essentialism & 2.55 & .92 & .58 & .33 \\
Existentialism & 4.56 & .61 & -2.67 & 11.15 \\
Reconstructivism & 3.91 & .71 & -.45 & .79 \\
Availability of Facilities & 1.71 & .33 & .86 & 1.39 \\
Belief that they are important & 2.74 & .32 & -2.01 & 5.49 \\
Learning depends on effort & 2.10 & .55 & 1.13 & 4.96
\end{tabular}


Learning depends on ability

There is a unique truth

$\begin{array}{llll}2.54 & .94 & .95 & .40 \\ 2.97 & .81 & .55 & .14\end{array}$

After inspection of assumptions, the construct validity of data collection tools was examined through confirmatory factor analysis. The fit indices can be seen in Table 2.

Table 2. The goodness of fit indices obtained during CFA

\begin{tabular}{|c|c|c|c|c|c|c|}
\hline Index & CLBS & EDBS & PDS-A & PDS-I & EPBS & Thresholds \\
\hline$X^{2}$ & 774.95 & 1986.41 & $1115 \cdot 34$ & 1271.37 & 1618.95 & \\
\hline$P$ & .00 & .00 & .00 & .00 & .00 & 2.05 (Hair et al., 2006; Hoyle, 1995). \\
\hline $\mathrm{X}^{2} / \mathrm{df}$ & 2.73 & 2.72 & 3.74 & 4.28 & 2.91 & $\begin{array}{l}\leq 3(\text { Kline }, 2000) \\
\leq 5(\text { Bollen, 1989a })\end{array}$ \\
\hline GFI & .82 & .74 & .76 & .74 & .75 & $\begin{array}{l}\geq 85 \text { (Joreskog and Sorbom, 1988). } \\
\geq .90 \text { (Hair et al., 2006). } \\
\geq .80 \text { (Marsh, Balla, \& McDonald, 1988). }\end{array}$ \\
\hline AGFI & .78 & .70 & .72 & .69 & .72 & $\begin{array}{l}\geq .90 \text { (Hair et al., 2006; Maccallum \& Hong, } \\
\text { 1997). }\end{array}$ \\
\hline RMSEA & .08 & .08 & .10 & .11 & .08 & 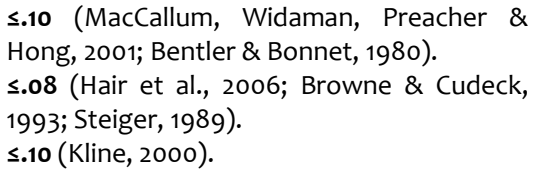 \\
\hline SRMR & .05 & .09 & .08 & .07 & .13 & $\begin{array}{l}\leq .08 \text { (Tabachnick \& Fidell, 2007; Hair et al., } \\
\text { 2006; Hu \& Bentler, 1999). }\end{array}$ \\
\hline NFI & .96 & .92 & .87 & .93 & .88 & $\begin{array}{l}\geq .80 \text { (Marsh, Balla, \& McDonald, 1988; } \\
\text { Bentler \& Bonett, 1980). }\end{array}$ \\
\hline NNFI & .97 & .94 & .89 & .94 & .91 & $\begin{array}{l}\text { \.90 (Vidaman \& Thompson, 2003; Bentler \& } \\
\text { Bonett, 1980). }\end{array}$ \\
\hline $\mathrm{CFI}$ & .98 & .95 & .90 & .94 & .92 & $\begin{array}{l}\text { ×.90 (Vidaman \& Thompson, 2003; Bentler, } \\
\text { 1990; Bentler \& Bonett, 1980). }\end{array}$ \\
\hline IFI & .98 & .95 & .90 & .94 & .92 & $\geq .90$ (Bollen, 1989b). \\
\hline PNFI & .84 & .86 & .80 & .85 & .83 & $\begin{array}{l}\text { >.50 (Mualik, James, Van Alstine, Bennett, } \\
\text { Lind \& Stilwell, 1989). }\end{array}$ \\
\hline PGFI & .67 & .65 & .65 & .62 & .66 & $>.60$ (Byrne, 2010). \\
\hline
\end{tabular}

Note: CLBS = Constructivist Learning Belief Scale, EDBS = Educational Belief Scale, PDS-A = Professional Development Scale - Availability of Facilities, PDS-I = Professional Development Scale - Importance of Facilities, EPBS = Epistemological Belief Scale.

It can be seen in Table 2 that most of the indices were within the acceptable thresholds. After the inspection of structural equation modelling assumptions and construct validity of data collection tools, all of the hypotheses related to the proposed model were tested. However, this model did not yield the results within acceptable limits. In order to solve this problem, the influences of philosophical beliefs, epistemological beliefs, and professional development facilities on constructivist learning beliefs were examined independently. Three variables, namely learning is dependent on effort $(\mathrm{H} 6)$, there is a unique truth $(\mathrm{H} 8)$, and the availability of professional development opportunities ( $\mathrm{H9}$ ), were observed to contribute to the model poorly. Thus, these variables were excluded from the proposed model resulting in a structural equation model within acceptable limits (Model A).

\section{Model A}

The goodness of fit indices of model A were examined. $X^{2} / \mathrm{df}$ ratio of the model was below 3 , indicating a good model fit (Kline, 2005). RMSEA and SRMR were also observed to support the model fit. However, GFI and AGFI were too distant to the acceptable levels. The literature 
emphasizes that these two values can be negatively affected by model complexity (Hair et al., 2006). The proposed model is complex composed of over 110 observed and 8 latent variables. The goodness of fit indices are presented in Table 3.

Table 3. The goodness of fit indices of both models and thresholds

\begin{tabular}{|c|c|c|c|}
\hline Index & Model A & Model B & Thresholds \\
\hline $\mathrm{X}^{2}$ & 10534.37 & 10559.69 & \\
\hline$P$ & .00 & .00 & 2.05 (Hair et al., 2006; Hoyle, 1995). \\
\hline $\mathrm{X}^{2} / \mathrm{df}$ & 2.02 & 2.02 & $\begin{array}{l}\leq 3 \text { (Kline, 2000) } \\
\leq 5 \text { (Bollen, 1989a) }\end{array}$ \\
\hline GFI & .58 & .58 & $\begin{array}{l}\geq 85 \text { (Joreskog and Sorbom, 1988). } \\
\geq .90 \text { (Hair et al., 2006). }\end{array}$ \\
\hline AGFI & .56 & .56 & $\begin{array}{l}\geq .80 \text { (Marsh, Balla, \& McDonald, 1988). } \\
\geq .90 \text { (Hair et al., 2006; Maccallum \& Hong, 1997). } \\
\leq .10 \text { (MacCallum, Widaman, Preacher \& Hong, 2001; Bentler \& Bonnet, }\end{array}$ \\
\hline RMSEA & .061 & .061 & $\begin{array}{l}\text { 1980). } \\
\leq .08 \text { (Hair et al., 2006; Browne \& Cudeck, 1993; Steiger, 1989). }\end{array}$ \\
\hline SRMR & .073 & .074 & $\begin{array}{l}\leq .10 \text { (Kline, 2000). } \\
\leq .08 \text { (Tabachnick \& Fidell, 2007; Hair et al., 2006; Hu \& Bentler, 1999). }\end{array}$ \\
\hline NFI & .88 & .88 & $\geq .80$ (Marsh, Balla, \& McDonald, 1988; Bentler \& Bonett, 1980). \\
\hline NNFI & .93 & .93 & 2.90 (Vidaman \& Thompson, 2003; Bentler \& Bonett, 1980). \\
\hline CFI & .93 & .93 & $\begin{array}{l}\text { z.90 (Vidaman \& Thompson, 2003; Bentler, 1990; Bentler \& Bonett, } \\
\text { 1980). }\end{array}$ \\
\hline IFI & .93 & .93 & $\geq .90$ (Bollen, 1989b). \\
\hline PNFI & .86 & .86 & >.50 (Mualik, James, Van Alstine, Bennett, Lind \& Stilwell, 1989). \\
\hline PGFI & .55 & .55 & $>.60$ (Byrne, 2010). \\
\hline
\end{tabular}

Incremental fit indices were mostly above .90, indicating a good model fit. In this group, only NFI was below .90. However, some studies indicate that an NFI value of .80 or above can be accepted (Marsh, Balla and McDonald, 1988; Bentler and Bonett, 1980). When the parsimony indices were examined, it was observed that PNFI was above the acceptable cutoff values, indicating the simplicity of the model. Also, PGFI yielded a value close to the quality fit cutoff. Hair et al. (2006) define the acceptable model characteristics for studies having a sample bigger than 250 and 30 or more observed variables as; significant p-values, SRMR $<=.80$ with CFI above .92, and RMSEA <.07 with CFI>=.90. The obtained goodness of fit indices meet most of these criteria.

The path coefficients of the hypotheses are presented in Table 4, and the causal model and standard coefficients are presented in Figure 1.

Table 4. Path coefficients and their significance related to model A

\begin{tabular}{lllll}
\hline $\begin{array}{l}\text { Hypothesis } \\
\text { number }\end{array}$ & $\begin{array}{l}\text { Proposed } \\
\text { hypothesis }\end{array}$ & Path coefficient & t-value & Results \\
\hline $\mathrm{H} 1$ & Prog. $\rightarrow$ Const. & 0.68 & $3.55^{* *}$ & Supported \\
$\mathrm{H} 2$ & Per. $\rightarrow$ Const. & -0.22 & 1.54 & Not Supported \\
$\mathrm{H} 3$ & Ess. $\rightarrow$ Const. & 0.22 & 1.57 & Not Supported \\
$\mathrm{H} 4$ & Ex. $\rightarrow$ Const. & -0.14 & 1.08 & Not Supported \\
$\mathrm{H}_{5}$ & Rec. $\rightarrow$ Const. & 0.09 & 0.89 & Not Supported \\
$\mathrm{H} 7$ & Abi. $\rightarrow$ Const. & -0.22 & $2.11^{*}$ & Supported \\
$\mathrm{H} 10$ & Imp. $\rightarrow$ Const. & 0.13 & 1.81 & Not Supported
\end{tabular}




\begin{tabular}{lll} 
H6 & Eff. $\rightarrow$ Const. & It wasn't tested since it decreased the model quality. \\
H8 & Tru. $\rightarrow$ Const. & It wasn't tested since it decreased the model quality. \\
H9 & Imp. $\rightarrow$ Const. & It wasn't tested since it decreased the model quality. \\
\hline${ }^{* *} \mathrm{p}<.01,{ }^{*} \mathrm{p}<.05$ &
\end{tabular}

When the path analysis results of model $\mathrm{A}$ were examined, it was observed that only $\mathrm{H} 1$ and $\mathrm{H} 7$ were confirmed. Accordingly, progressivism predicted constructivist learning beliefs significantly and positively while the belief that learning depends on effort predicted constructivist learning beliefs significantly and negatively.

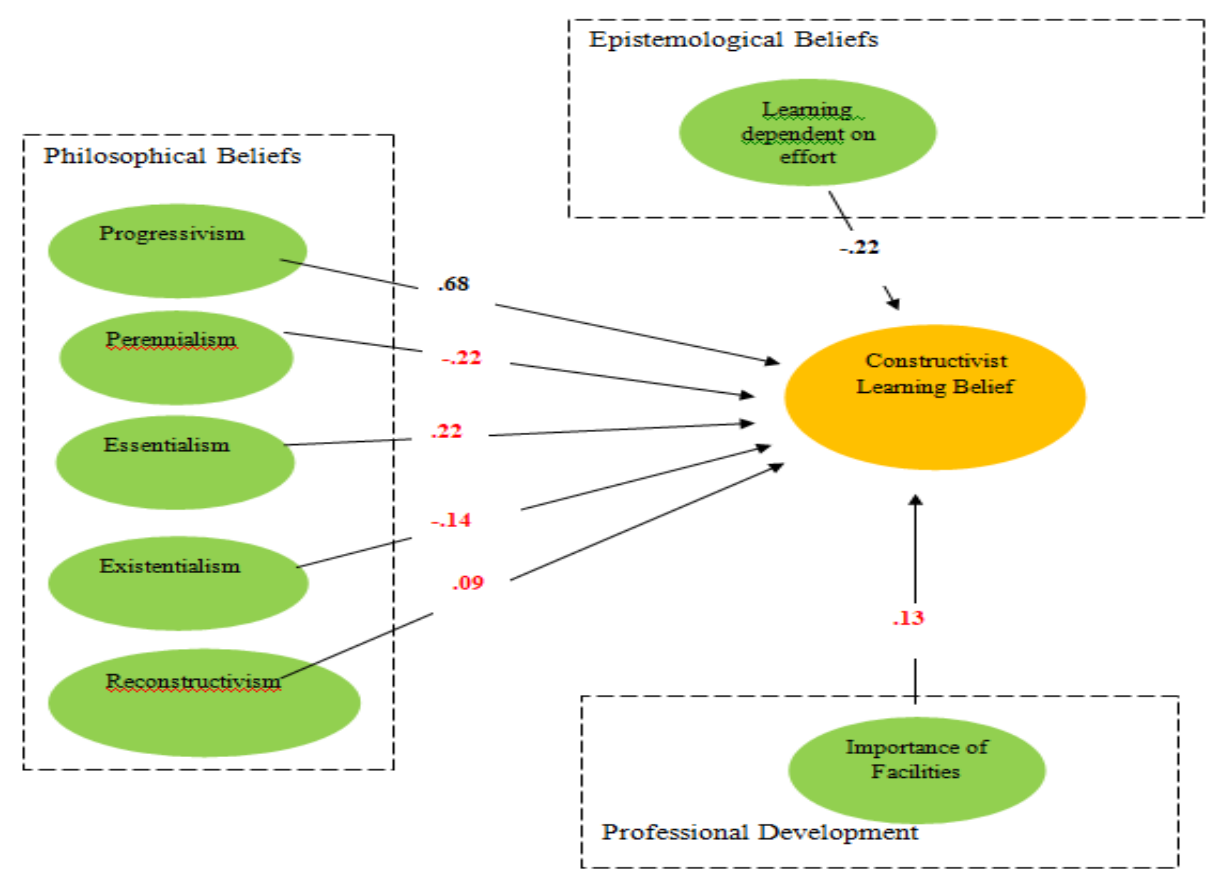

Figure 2: The casual model and standard values related to Model A.

\section{Model B}

Teachers' beliefs about the importance of professional development were observed to predict their constructivist learning beliefs significantly as a result of the analyses of independent paths between the beliefs regarding professional development and constructivist learning beliefs. However, this impact was not able to be observed in the integrated model. As a result of inquiries related to the reason for this situation, it was decided that beliefs about educational philosophies, especially progressivism and reconstructivism, might have had significant influences on the importance given to professional development by teachers. Supportively, Bas (2015) revealed significant relationships between teachers' progressivist, reconstructivist, and existentialist beliefs and their choices of constructivist teaching. Based on both this finding and the experience obtained in Model A, Model B was proposed and tested. Model B involved the hypotheses below: 
Hb1: Teachers' progressivist beliefs predict their constructivist learning beliefs positively and significantly.

Hb2: Teachers' prennialist beliefs predict their constructivist learning beliefs negatively and significantly.

Hb3: Teachers' essentialist beliefs predict their constructivist learning beliefs negatively and significantly.

Hb4: Teachers' existentialist beliefs predict their constructivist learning beliefs positively and significantly.

Hb5: Teachers' reconstructivist beliefs predict their constructivist learning beliefs positively and significantly.

Hb6: Teachers' beliefs that learning depends on the ability predict their constructivist learning beliefs negatively and significantly.

Hb7: The importance given to professional development predicts their constructivist learning beliefs positively and significantly.

Hb8: Teachers' progressivist beliefs predict the importance given to professional development positively and significantly.

Hb9: Teachers' reconstructivist beliefs predict the importance given to professional development positively and significantly.

Based on these hypotheses, the causal model was tested using structural equation modelling. The goodness of fit indices regarding Model B can be seen in Table 3. The examination of fit indices revealed that most of them were within an acceptable range similar to Model $A$. Depending on this finding, path values were examined. Path values and their significance are presented in Table 5 .

Table 5. Path coefficients and their significance related to model B

\begin{tabular}{lllll}
\hline $\begin{array}{l}\text { Hypothesis } \\
\text { number }\end{array}$ & $\begin{array}{l}\text { Proposed } \\
\text { hypothesis }\end{array}$ & Path coefficient & t-value & Results \\
\hline $\mathrm{H}_{\mathrm{b} 1}$ & Prog. $\rightarrow$ Const. & 0.65 & $3.67^{* *}$ & Supported \\
$\mathrm{H}_{\mathrm{b} 2}$ & Per. $\rightarrow$ Const. & -0.22 & 1.56 & Not Supported \\
$\mathrm{H}_{\mathrm{b} 3}$ & Ess. $\rightarrow$ Const. & 0.21 & 1.56 & Not Supported \\
$\mathrm{H}_{b} 4$ & Ex. $\rightarrow$ Const. & -0.12 & .96 & Not Supported \\
$\mathrm{H}_{b 5}$ & Rec. $\rightarrow$ Const. & 0.09 & .87 & Not Supported \\
$\mathrm{H}_{b} 6$ & Abi. $\rightarrow$ Const. & -0.20 & $2.05^{* *}$ & Supported \\
$\mathrm{H}_{b} 7$ & Imp. $\rightarrow$ Const. & 0.15 & $2.33^{*}$ & Supported \\
$\mathrm{H}_{b} 8$ & Prog. $\rightarrow$ Imp. & 0.53 & $4.88^{* *}$ & Supported \\
$\mathrm{H}_{b} 9$ & Rec. $\rightarrow$ Imp. & -0.15 & 1.73 & Not Supported \\
\hline${ }^{* *} \mathrm{p}<.01,{ }^{*} \mathrm{p}<.05$ & & &
\end{tabular}

When the path values of Model $B$ were examined, it was observed that $\mathrm{H}_{b} 1, \mathrm{H}_{b} 6, \mathrm{H}_{b} 7$, and $\mathrm{H}_{\mathrm{b}} 8$ were supported. This situation showed that progressivism predicted both constructivist learning beliefs and the importance given to professional development positively and significantly. Moreover, when the impacts of progressivism and reconstructivism on the importance given to professional development were considered, it was observed that the importance given to professional development predicted constructivist teaching beliefs positively and significantly. The causal model and standard coefficients of Model B are presented in Figure 3. 


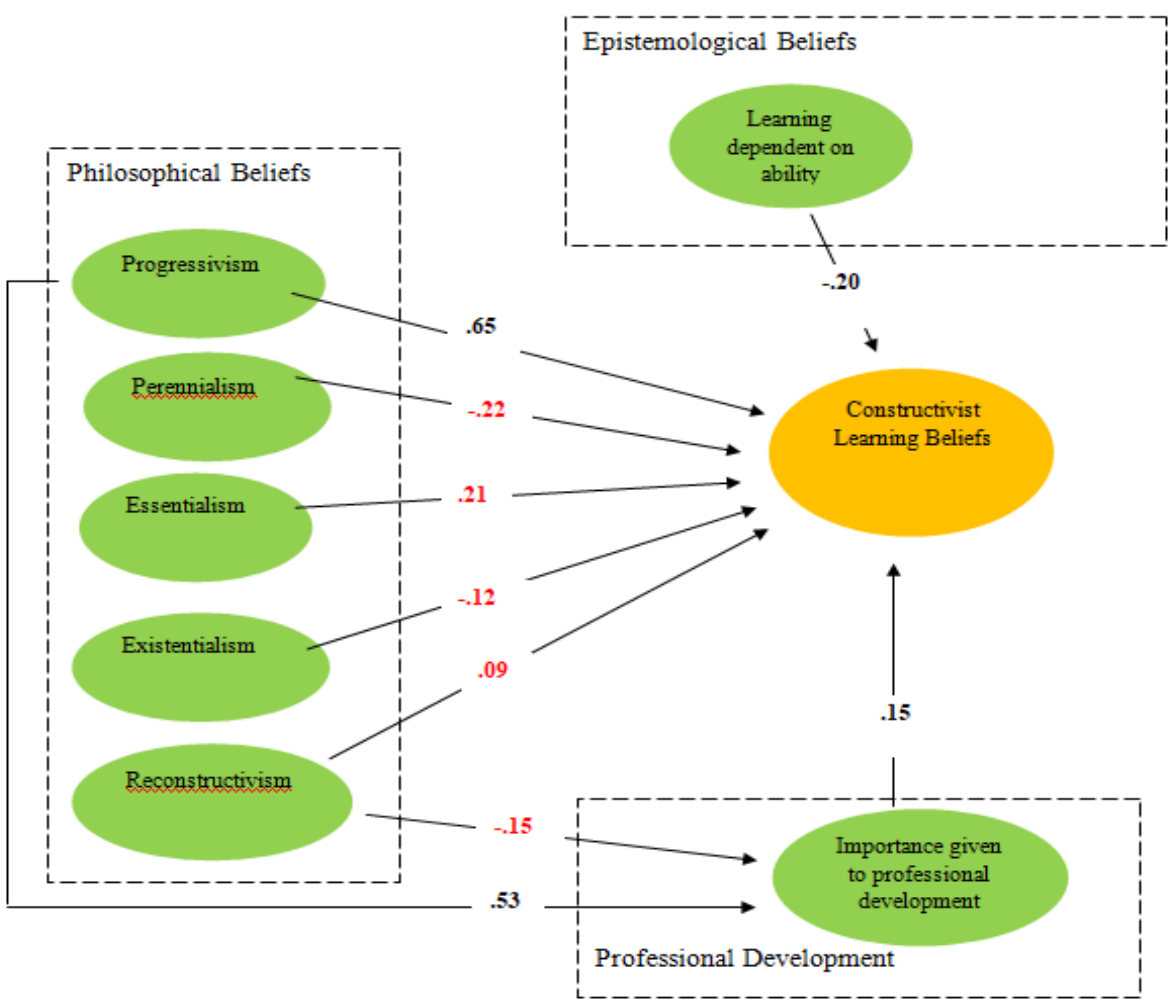

Figure 3. The casual model and standard coefficients of Model B.

\section{Discussion and Conclusion}

In this study, the impact of teachers' beliefs of educational philosophies, epistemological beliefs, access to professional development facilities, and importance attached to these facilities on their constructivist learning beliefs was investigated through structural equation modelling. The results showed that both philosophical beliefs, epistemological beliefs, and their perceptions regarding professional development significantly predicted their constructivist learning beliefs.

When the philosophical beliefs were examined, it was observed that progressivism had positive and significant impacts on constructivist learning beliefs $\left(H_{a} 1, H_{b} 1\right)$. This philosophical belief was observed to be the most significant predictor of constructivist learning beliefs in both models. This situation shows that constructivist learning beliefs were predicted by philosophical beliefs, especially progressivism, most among the variables included in this study. Preliminary studies reveal similar results (Bas, 2015; Sahan and Terzi, 2015; Chan and Eliot, 2004). For example, Bas (2015) found that there were significant and positive relationships between teachers' progressivist, reconstructivist, and existentialist beliefs and their constructivist learning beliefs; however, there were negative and significant relationships between essentialist and prennialist philosophies and their constructivist learning beliefs. The strong relationship between progressivism and constructivist learning beliefs might be sourced from the learners' central role and responsibility given during the 
learning process in both approaches (Bas, 2015). At this point, it isn't unexpected for essentialist $\left(\mathrm{H}_{\mathrm{a}} 3, \mathrm{H}_{\mathrm{b}} 3\right)$ and prennialist $\left(\mathrm{H}_{\mathrm{a}} 2, \mathrm{H}_{\mathrm{b}} 2\right)$ beliefs, which is more solid and authoritarian during the creation and dissemination of knowledge, to have a negative impact on constructivist learning beliefs because there is an apparent distinction between essentialist and prennialist philosophies, where the learner is passive, and the constructivist learning beliefs, where the learner actively take part in every step of learning.

An unexpected and interesting finding of the study was that existentialist and reconstructivist philosophies did not have a significant effect on constructivist learning beliefs. However, researchers have a fundamental acknowledgment that curiosity and beliefs of these philosophies are the main motivation behind the constructivist practices (Honey and McArthur, 2001; Ravitz, Becker and Von, 2000; Sahan and Terzi, 2015). This situation can be acceptable for a preliminary period in which constructivism was seen as an alternative to traditional teaching and constructivist practices were mostly carried out due to the teachers' internal motivations. However, some reflections involving the expectations of generation $z$ from education, school, and teacher, the effects of the information age on the phenomenon of education and its process, $21^{\text {st }}$-century skills, and goals of sustainable development make constructivism a prerequisite for a "good teacher" rather than an alternative. With this understanding at hand, the participants might have been leaning towards constructivist practices so that they could do the teaching job better due to external motivation and directions in the Turkish education system. From this viewpoint, the relationship between progressive philosophy and constructivist learning beliefs can be placed in a context that involves the efforts to become a better teacher and social progress.

Among the epistemological beliefs, the belief that learning depends on ability had significant and negative impacts on constructivist learning beliefs $\left(\mathrm{H}_{\mathrm{b}} 7\right)$. In other words, the more the teachers believe that learning depends on ability, the less their constructivist learning beliefs are. However, the beliefs that learning depends on effort and there is a unique truth didn't have any impact on constructivist learning beliefs. When it is considered that learning is equal to experience in constructivism (Jonassen, 1991), it is not an unexpected result that the belief of learning ability had a negative impact on constructivist learning beliefs. Studies supporting this finding are present in the literature. For example, in their study conducted with teachers, Lee, Zhang, Song, and Huang (2013) found that the beliefs that learning depends on ability and certainty of knowledge positively predicted traditional teaching beliefs while it negatively predicted constructivist teaching beliefs. Similarly, in a study conducted with preservice teachers, Tezci, Erdener and Atici (2016) found that the beliefs that learning depends on ability and certainty of knowledge negatively predicted constructivist teaching beliefs, while it positively predicted traditional teaching beliefs. The belief that learning depends on effort positively predicted constructivist teaching beliefs, while it negatively predicted traditional teaching beliefs. At this point, an unexpected result of the current study is that the belief that learning depends on effort didn't have any impact on constructivist learning beliefs $\left(H_{a} 6\right)$. A possible explanation for this situation might be the model complexity and the moderators that aren't included in the model. Therefore, future studies are recommended to examine this relationship using more parsimonious models. On the other hand, some studies in the literature found no or negative relationship between the belief that learning depends on effort and constructivist teaching beliefs (Chan and Elliot, 2004; Otting, Zwaal, Tempelaar and Gijselaers, 2010). Perhaps, it is necessary to mention the possible cultural and contextual impacts on the belief that learning depends on effort. In countries where the central exams are used in various steps of basic education such as Turkey, the expectations of teachers 
regarding the students' successes in these exams are a factor that increases teachers' beliefs of the role of effort in learning (Aypay, 2011). From this viewpoint, it can be assumed that both constructivist and traditionalist teachers share the belief that learning depends on effort. Moreover, the literature shows that teachers' beliefs of the role of effort in learning may differ in terms of their branches. Especially, teachers in social sciences adopt these beliefs more when compared with their counterparts in science (Taskin, 2012). Therefore, these complex relations might be making it difficult to reveal the relationship between the belief that learning depends on effort and constructivist teaching beliefs.

According to the results, teachers' beliefs regarding the professional development facilities were one of the significant predictors of their constructivist learning beliefs. The importance attached to these facilities positively and significantly predicted their constructivist learning beliefs $\left(\mathrm{H}_{\mathrm{b}} 7\right)$. This situation means that an increase in the importance attached to professional development facilities will result in an increase in their constructivist learning beliefs. Similarly, activities aiming at facilitating professional development and increasing importance attached to professional development increase teachers' tendency to adopt constructivist learning approaches. For example, Gul (2016) found that teacher development seminars, which aimed at developing awareness of the importance of professional development, resulted in a positive change in teachers' constructivist views, approaches, and practices. Colak (2017) states that professional learning communities yielded a change in teachers' lesson plans towards a more constructivist approach. Similarly, Mansour (2013) underlines that the classroom and school social communities should be transformed into more active learning communities so that a constructivist viewpoint could be adopted in science teaching.

The results showed that philosophical beliefs regarding innovation in education may have an impact on the importance attached to professional development. Especially progressivist beliefs positively and significantly predicted the importance attached to professional development $\left(\mathrm{H}_{\mathrm{b}} 8\right)$. In a study conducted with preservice physical education teachers, Erbas (2014) revealed similar results. Accordingly, there was a positive and high correlation between progressivist beliefs and attitudes towards ICT use in teaching, which can be regarded as an indicator of importance attached to professional education. This situation clearly shows that teachers' positive beliefs of progressivism may contribute to constructivist learning beliefs both directly and indirectly through the importance attached to professional development.

When this study is evaluated from a holistic perspective, two impacts that are quantitative and qualitative sourcing from the methods and the tools can be expressed. The quantitative part involves the number of participants and the model complexity because structural equation modelling is sensitive to the number of observed variables and sample size in terms of both path coefficients and fit indices. Two parameters are used in terms of model complexity/number of participants. Researchers need to maintain the balance between these two ratios. The first one is the 200 participants threshold recommended to obtain quality path and fit values in structural equation modelling (Kline 2011; Khine et al., 2013). This number is met in the current study. The second parameter is the ratio of the sample size to the number of observed variables (items) as 10 times or 20 times (Kline, 2011; Schumacker and Lomax, 2010). The number of participants is 2.5 times the number of items in the current study. Therefore, it is possible to state that this limitation might impact the obtained values in the study. 
The impact of simultaneous responding of different data collection tools and simultaneous analysis of the data should be considered in terms of the qualitative part. As in every other similar study, a response given to an item in a data collection package is likely to affect other responses and the model complexity increases the likelihood of this effect. This undesired effect is likely to be observed on the parameters that are obtained during the path analysis.

\section{References}

Aguinis, H., Gottfredson, R. K. \& Joo, H. (2013). Best-practice recommendations for defining, identifying, and handling outliers. Organizational Research Methods, 16 (2), 270-301.

Anagun, S. S., Yalcinoglu, P. \& Ersoy, A. (2012). Sinif ogretmenlerinin fen ve teknoloji dersi ogretme-ogrenme surecine iliskin inanclarinin yapilandirmacilik acisindan incelenmesi. Kuramsal Egitimbilim Dergisi, 5 (1), 1-16.

Arslan, A. (2009). Yapilandirmaci ogrenme yaklasimi ve Turkce ogretimi. Ataturk Universitesi Sosyal Bilimler Enstitusu Dergisi, 13 (1), 143-154.

Aypay, A. (2011). Ogretme ve ogrenme anlayislari olcegi'nin Turkiye uyarlamasi ve epistemolojik inanclar ile ogretme ve ogrenme anlayislari arasindaki iliskiler. Kuram ve Uygulamada Egitim Bilimleri 11 (1), 7-29.

Bahcivan, E. (2016). Investigating the relationships among PSTs' teaching beliefs: are epistemological beliefs central?. Educational Studies, 42:2, 221-238, DOI: 10.1080/03055698.2016.1160823

Bas, G. (2015). Correlation between teachers' philosophy of education beliefs and their teaching-learning conceptions. Education and Science 40 (182), 111-126.

Bentler, P. M. \& Bonett, D. G. (1980). Significance tests and goodness of fit in the analysis of covariance structures. Psychological Bulletin 88 (3), 588-606.

Bentler, P. M. (1990). Fit indexes, Lagrange multipliers, constraint changes and incomplete data in structural models. Multivariate Behavioral Research 25 (2), 163-172.

Berlin, D. F., Klapper, M. H. \& White, A. L. (1996). Defining a professional environment for teaching. In annual meeting of the National Association for Research in Science Teaching, St. Louis, Missouri.

Bicer, B., Er, H. \& Ozel, A. (2013). Ogretmen adaylarinin epistemolojik inanclari ve benimsedikleri egitim felsefeleri arasindaki iliski. Egitimde Kuram ve Uygulama 9 (3), 229-242.

Bollen, K. A. (1989a). Structural equations with latent variables. New York: Wiley Publications

Bollen, K. A. (1989b). A new incremental fit index for general structural equation models. Sociological Methods and Research 17 (3), 303-316.

Browne, M. W. \& Cudeck, R. (1993). Alternative ways of assessing model fit. In: Testing Structural Equation Models edited by K. A. Bollen \& J. S. Long, 136-162. Sage focus editions.

Bryan, L. (2012). Research on science teacher beliefs. In: Second International Handbook of Science Education edited by B. Fraser, K. Tobin, \& C. McRobbie, 477-495. Springer International.

Buckner, E. (2016). The changing discourse on higher education and the nation-state, 19602010. Higher Education 74 (3), 473-489. DOI:10.1007/s10734-016-0056-2

Byrne, B. M. (2013). Structural equation modeling with EQS: Basic concepts, applications, and programming. New York: Routledge. 
Cam, A. (2015). Primary pre-service teachers' epistemological beliefs and their teaching and learning experiences. Eurasia Journal of Mathematics, Science and Technology Education 11 (2), 381-390.

Celikoz, M. \& Erisen, Y. (2017). Constructivist practice in the curriculum and instruction: the views of lecturers in the field. International Online Journal of Educational Sciences, 2017, X (X), X-X.

Chan, K-W. \& Elliot, R. G. (2004). Relational analysis of personal epistemology and conceptions about teaching and learning. Teaching and Teacher Education 20, 817-831.

Cohen, L., Manion, L. \& Morrison, K. (2005). Research methods in education (5th ed.). USA: Taylor \& Francis.

Colak, E. (2017). Teachers' experiences in a professional learning community on the constructivist lesson planning: a case study among primary school teachers. Education and Science 42 (190), 189-209.

Cronin-Jones, L. (1991). Science teaching beliefs and their influence on curriculum implementation: two case studies. Journal of Research in Science Teaching 38 (3), 235250.

Deryakulu, D. \& Buyukozturk, S. (2002). Epistemolojik inanc olceginin gecerlik ve guvenirlik calismasi [Validity and reliability study of epistemological beliefs questionnaire]. Egitim Arastirmalari 8, 111-125.

Deryakulu, D. (2000). Yapici ogrenme [Constructive learning]. In: Sinifta demokrasi [Democracy in classroom] edited by A. Simsek, 53-77. Ankara: Egitimsen Yayinlari.

Duru, S. (2006). The influences on teacher identity and the suggestions for the new teacher identities. Eurasian Journal of Educational Research 22, 121-131.

Ekici, F., Aldan Karademir, C. Ucak, E. \& Ekici, E. (2011). Primary school teachers' opinions and application levels related to constructivist approach to the subjects of voice and light. Eurasian J. Phys. Chem. Educ. 3 (2), 112-126.

Ekinci, N. (2017). Examining the relationships between epistemological beliefs and teaching and learning conceptions of lower-secondary education teachers. Inonu Universitesi Egitim Fakultesi Dergisi 18 (1), 344-358.

Erbas, M. K. (2014). The effects of preservice physical education teachers' educational beliefs on their attitudes toward computer and internet usage. IBB International Refereed Academic Social Sciences Journal 16 (5), 138-151.

Erdem, M. \& Arkun Kocadere, S. (2015). Yapilandirmaci ogrenme inanc olceginin gelistirilmesi. Ilkogretim Online 14 (4), 1260-1275.

Ertmer, P. \& Newby, T. (2013). Behaviorism, cognitivism, constructivism: comparing critical features from an instructional design perspective. Performance Improvement Quarterly 26 (2), 43-71.

Ertmer, P. A. (2005). Teacher pedagogical beliefs: the final frontier in our quest for technology integration? ETRandD 53 (4), 25-39.

Gul, A. (2016). Constructivism as a new notion in English language education in Turkey. Ph.D. diss., Kent State University. Retrieved from https://etd.ohiolink.edu/

Gutek, G. L. (1997). Philosophical and ideological perspectives on education. Boston: Allyn \& Bacon.

Hair, J. F., Black, W. C., Babin, B. J., Anderson, R. E. \& Tatham, R. L. (2006). Multivariate data analysis. Upper Saddle River: Pearson Prentice Hall.

Haney, J. J. \& McArthur, J. (2002). Four case studies of prospective science teachers' beliefs concerning constructivist teaching practices. Science Education, 86(6), 783-802. 
Howard, B. C., McGee, S., Schwartz, N. \& Purcell, S. (2000). The experience of constructivism: transforming teacher epistemology. Journal of Research on Computing in Educatio, 32 (4), 455-465.

Howe, N., Jacobs, E., Vukelich, G. \& Recchia, H. (2012). In-service professional development and constructivist curriculum: effects on quality of child care, teacher beliefs, and interactions. Alberta Journal of Educational Research 57 (4), 353-378.

Hoyle, R. H. (1995). Structural equation modeling: Concepts, issues, and applications. Sage.

Hu, L. T. \& Bentler, P. M. (1999). Cutoff criteria for fit indexes in covariance structure analysis: Conventional criteria versus new alternatives. Structural Equation Modeling: $A$ Multidisciplinary Journal 6 (1), 1-55.

Huang, J. C. (2014). A study of teachers' epistemological beliefs, goal setting, and teaching volition in the teachers' professional learning communities: the cases of primary school. Bulletin of Educational Research 60(1), 39-76. DOI:10.3966/102887082014036001002

Ismail, M. (2017). EFL teachers' epistemological beliefs and their assessment orientations. International Journal of Applied Linguistics and English Literature 6 (1), 99-114. DOI:10.1080/21679169.2016.1233995

Jonassen, D. (1991). Objectivism versus constructivism: do we need a new philosophical paradigm? ETRandD 39 (3), 5-14.

Joreskog, K. G. \& Sorbom, D. (1988). Prelis. in A program for multivariate data screening and data summarization. User's Guide. Chicago: Scientific Software International.

Khine, M.S., Afari, E., Aldridge, J., Bergen, T. \& DiStefano, C. (2013). Application of structural equation modeling in educational research and practice. Rotterdam, Netherlands: Sense Publishers.

Kim, J. (2016). Development of a global lifelong learning index for future education. Asia Pacific Education Review 17 (3), 439-463. DOI:10.1007/s12564-016-9445-6

Kirschner, P. (2009). Epistemology or pedagogy, that is the question. In Constructivist Instruction: Success or Failure?. edited by S. Tobias \& T. Duffy, 144-157. New York: Routledge.

Kline, B. R. (2011). Principles and practice of structural modeling (3rd ed.). New York-London: The Guilford Press.

Kline, P. (2000). Handbook of Psychological Testing (second ed.). London and Newyork: Routledge.

Kline, P. (2005). Principles and practice of structural equation modeling. New York: Guilford Publications.

Lee, J., Zhang, Z., Song, H. \& Huang, X. (2013). Effects of epistemological and pedagogical beliefs on the instructional practices of teachers: A Chinese perspective. Australian Journal of Teacher Education 38 (12), 120-146.

Levitt, L. (2001). An analysis of elementary teachers' beliefs regarding the teaching and learning of science. Science Education 86, 1-22.

Lumpe, A., Haney, J. \& Czerniak, C. (2000). Assessing teachers' beliefs about their science teaching context. Journal of Research in Science Teaching 37, 275-292.

MacCallum, R. C. \& Hong, S. (1997). Power analysis in covariance structure modeling using GFI and AGFI. Multivariate Behavioral Research 32 (2), 193-210.

MacCallum, R. C., Widaman, K. F., Preacher, K. J. \& Hong, S. (2001). Sample size in factor analysis: The role of model error. Multivariate Behavioral Research 36 (4), 611-637.

Mansour, N. (2013). Consistencies and inconsistencies between science teachers' beliefs and practices. International Journal of Science Education 35 (7), 1230-1275, DOI: 10.1080/09500693.2012.743196 
Marsh, H. W., Balla, J. R. \& McDonald, R. P. (1988). Goodness-of-fit indexes in confirmatory factor analysis: The effect of sample size. Psychological Bulletin 103 (3), 391-410.

Mulaik, S. A., James, L. R., Van Alstine, J., Bennett, N., Lind, S. \& Stilwell, C. D. (1989). Evaluation of goodness-of-fit indices for structural equation models. Psychological Bulletin 105 (3), 430-445.

Oliva, P. (1988). Developing the curriculum. USA: Scott, Foresman and Company.

Ornstein, A. \& Levine, D. (2008). Foundations of education. Boston: Houghton Mifflin Company.

Otting, H., Zwaal, W., Tempelaar, D. \& Gijselaers, W. (2010). The structural relationship between students' epistemological beliefs and conceptions of teaching and learning. Studies in Higher Education 35 (7), 741-760.

Ozmon, H. A. \& Craver, S. M. (2003). Philosophical foundations of education. New Jersey: Merrill Prentice Hall.

Pajares, F. (1992). Teachers' beliefs and education research: cleaning up a messy construct. Review of Educational Research 62 (3), 307-332.

Palmaru, R. (2016). Constructivism as a key towards further understanding of communication, culture and society. Constructivist Foundations 12 (1), 30-38.

Ravitz, J. L., Becker, H. J. \& Wong, Y. (2000). Constructivist-compatible beliefs and practices among us teachers. Teaching, learning, and computing: 1998 national survey report\# 4.

Richardson, V. (1996). The role of attitudes and beliefs in learning to teach. In Handbook of Research on Teacher Education edited by J. Sikula, 102-119. New York: Macmillan.

Sahan, H. H. \& Terzi, A. R. (2015). Analyzing the relationships between prospective teachers' educational philosophies and their teaching-learning approaches. Educational Research and Reviews 10 (8), 1267-1275. DOI: 10.5897/ERR2015.2166

Sahin, M., Kocagul, M. \& Guler, B. (2012). Ortaogretim ogretmenlerinin okul temelli mesleki gelisime yonelik ihtiyaclarinin belirlenmesi [Determination of secondary school teachers' needs for school-based professional development]. Poster presented at 6 . Uluslararasi Bilgisayar ve Ogretim Teknolojileri Sempozyumu, Gaziantep, 4-6 Ekim 2012.

Saylan, A., Armagan, F. \& Bektas, O. (2016). The relationship between pre-service science teachers' epistemological beliefs and preferences for creating a constructivist learning environment. European Journal of Science and Mathematics Education 4 (2), 251-167.

Schommer, M. (1990). The effects of beliefs about the nature of knowledge on comprehension. Journal of Educational Psychology 82, 498-504.

Schumacker, R. E. \& Lomax, R. G. (2010). A beginner's guide to structural equation modeling (third edition). New York, London: Routledge.

Shagrir, L. (2015). Working with students in higher education-professional conceptions of teacher educators. Teaching in Higher Education 20 (8), 783-794.

Steiger, J. H. (1990). Structural model evaluation and modification: An interval estimation approach. Multivariate Behavioral Research 25 (2), 173-180.

Tabachnick, B. G. \& Fidell, L. S. (2007). Using multivariate statistics (5th ed.). New York: Allyn and Bacon.

Tanner, D. \& Tanner, L. (2007). Curriculum development: Theory into practice. USA: Pearson.

Taskin, C. S. (2012). Epistemological beliefs: as predictors of preservice teachers' learning approaches. Mustafa Kemal Universitesi Sosyal Bilimler Enstitusu Dergisi 9 (19), 273285. 
Tezci, E., Erdener, M. A. \& Atici, S. (2016). The effect of pre-service teachers' epistemological beliefs on teaching approaches. Universal Journal of Educational Research, 4 (12A), 205-215.

Thomson, M. \& Gregory, B. (2013). Elementary teachers' classroom practices and beliefs in relation to US science education reform: reflections from within. International Journal of Science Education 35 (11), 1800-1823.

Tobin, K. \& Espinet, M. (1989). Impediments to Change: applications of coaching in high school science teaching. Journal of Research in Science Teaching 26 (2), 105-120.

Vidaman, K. F. \& Thompson, J. S. (2003). On specifying the null model for incremental fit indices in structural equation modeling. Psychological Methods 8 (1), 16-37.

Volles, N. (2014). Lifelong learning in the EU: changing conceptualisations, actors, and policies. Studies in Higher Education 41 (2), 343-363. DOI:10.1080/03075079.2014.927852

Wallace, C. (2014). Overview of the role of teacher beliefs in science education. In The Role of Science Teachers' Beliefs in International Classrooms edited by R. Evans, J. Luft, C. Czerniak, \& C. Pea, 16-34. Rotterdam: Sense Publishers.

Yilmaz, K., Altinkurt, Y. \& Cokluk, O. (2011). Egitim inanclari olceginin gelistirilmesi: gecerlik ve guvenirlik calismasi. [Developing the educational belief scale: the validity and reliability study]. Kuram ve Uygulamada Egitim Bilimleri 11 (1), 335-350.

Yousefzadeh, M. \& Azam, L. B. (2015). The effect of Iranian teachers' epistemological beliefs on their teaching practice. Advances in Language and Literary Studies 6 (6), 25-28.

Yuan, E. R. (2017). Exploring university-based teacher educators' teaching beliefs and practice: a Hong Kong study. Teaching in Higher Education 22, 259-273. DOI:10.1080/13562517.2016.1248393

\section{Biografical Notes:}

Dr. Salih Bardakci is an associate professor of Computer and Instructional Technologies Education in the Faculty of Education at Tokat Gaziosmanpasa University, Tokat, Turkey. His research interests are ICT integration into education, sociocultural learning theory, online learning environments, and teacher education.

Dilara Cayci Karakose has a doctoral degree from the Department of Educational Sciences. Her research interests include teacher education, research education at the Ph.D. level, and curriculum development and evaluation.

Derya Colkesen Alkis is an English instructor at Zile Dincerler Tourism and Hotel Management College at Tokat Gaziosmanpasa University. She is a Ph.D. student in the field of Curriculum and Instruction. Her research interests include teacher education, teaching and learning, and the use of technology in language education.

Dr. Muhammet Fatih Alkan works as an assistant professor in the Department of Educational Sciences at Tokat Gaziosmanpasa University. His research interests are teacher education, curriculum development and evaluation, and workplace learning of academics. 